\title{
Recommendation of a New Transit Performance Measure in the National Transit Database
}

\author{
Fatemeh Baratian-Ghorghi*, Ph.D. \\ Parsons Corporation \\ Hossein Ahmadianyazdi, M.Sc \\ Iran University of Science and Technology \\ * Corresponding Author
}

\begin{abstract}
The frequency of incidents negatively changes public perception with regard to the public safety in transit systems. The level of safety expressed as performance measures, ensures contractors and users that a quality safety level is maintained. Both the private and public sectors in the U.S. annually report accurate data to the National Transit Database (NTD) to be used in assessing the progress of the nation's public transportation systems. Although they must provide both the annual report and monthly reports including Safety and Security data, measures are only grouped into the indicators of efficiency and effectiveness of a system and there is a distinct lack of safety performance measures.

This paper makes a comparison between the safety indicator values in large and small areas, and finds the correlation between system effectiveness and safety measures. Comparison results provide evidence that not every effective system is safe. Finally, three safety indicators are suggested which enables transit agencies to find their system's weaknesses in terms of safety.
\end{abstract}

Keywords: Safety, Performance Measure, Service Effectiveness, National Transit Database, Transit System

\section{INTRODUCTION:}

The NTD, as the best national transit data source, can be used to compare service measures across the transit agencies in the U.S. All agencies benefiting from Urbanized Area Formula Program grants are required by FTA (1) to report certain statistical information to the NTD annually (2). However, organizations operating nine or fewer 
vehicles in a non-fixed-guideway service are free from the obligation of reporting. The results show how Federal Transit Administration (FTA) funds should be allocated to the transit agencies. Currently, the NTD includes the information gathered from 930 separate agencies all over the nation. Information is available for revenues, wages, maintenance, incidents, employee, expenses, amount of service provided (e.g., vehicle miles, vehicle hours, and days of service), and amount of service consumed (e.g., unlinked trips and passenger miles). This information is readily available for agencies, planners, researchers, and others (3). Measures in the NTD database are grouped into two basic dimensions of performance, namely efficiency and effectiveness. Efficiency indicators define the relationship between operating expenses and the number of vehicle hours or vehicle miles (often referred to as "Produced Output Type"). Effectiveness indicators, however, are categorized into two groups: the first group measures the operating expenses against passenger miles and unlinked passenger trips (often referred to as "Consumed Output Type") while the second group measures the unlinked passenger trips to the amount of service produced. As for the service effectiveness, the NTD has selected four of the many possible measures based on the availability of reported data. Still, there is a distinct lack of safety performance measures in the agency profiles reported to the NTD (5).

In this paper the appraisal of the transit system's safety through the use of performance measures is examined. A set of indicators was collected from many past studies, and the ones possible to calculate based on the available data are employed for the measurement of transit safety performance. Starting with an initial set of 11 performance indicators, correlation tests are used to find and suggest the proper indicators to assess transit safety performance for every single mode.

\section{LITERATURE REVIEW}

Many studies have strived to propose methods to identify indicators which can properly measure transportation system performance (6-14). Different agencies may use and report different performance measures consistent with their objectives. However, not every researcher proposes using multiple indicators. Gordon et al. (7) identified and gathered a set of performance measures for transit systems and then suggested the bests to be used. Authors considered several criteria in the selection process such as distribution of values in the variable to be normal-like, the ease of gathering data, and the percentage of missing data during the selection process. The safety performance measures they suggested were: 1,000,000 vehicle miles traveled (VMT) per accident and accident and revenue vehicle hours per accident.

Texas Transportation Institute (TTI) recognized performance indicators to measure and monitor the performance of mobility throughout Texas and at a national level (8). Researchers summarized 20 case studies of the mobility management programs with the best examples of performance measures such as accidents per 100,000 miles of service, incidents per 1,000 passenger boarding, rate of serious injuries among transit riders per 100 million passenger miles traveled (PMT), and the average age of revenue vehicle fleet. 
The United States Department of Transportation (USDOT) strategic plan, entitled "Transportation for a New Generation", outlined the performance measures related to achieving strategic goals of safety (9). For example, the rate of transit-related fatalities per 100 million PMT was selected as the indicator of safety performance and the related goal was its reduction from 1.13 in 2009 to 1.03 in 2013. in addition to the passenger and vehicle safety an additional indicator was considered to measure the non-occupant (pedestrian and bicycle) safety as well (i.e. non-occupant fatalities per 100 million VMT).

Phase I of the Valley Metro/Regional Public Transportation Authority Efficiency and Effectiveness Study (10) listed the performance measures and related targets for transportation system performance factors. They used the safety incidents per 100,000 VMT as the only safety indicator of their transit system. Another study provided a summary of best existing practices in transit service planning and explained how to calculate safety performance measures (11). For example, no more than 6 accidents may occur per 100,000 miles operated. Fielding (1992) examined three programs: Federal Triennial Reviews, California Performance Audits and the Los Angeles Program. He used factor analytic techniques to reduce 48 transit performance indicators to a smaller set of measures, resulting in a model with 7 factors and 7 key variables, termed "markers" (12). The only safety indicator he used was the total vehicle miles between accidents.

Livermore Amador Valley Transportation Authority (LAVTA) (14) used three performance measures to assess their transit system, including traffic accidents per 100,000 VMT, passenger injury per 100,000 passenger boarding, percentage of preventive maintenance inspections completed within $10 \%$ of scheduled mileage.

The Transit Cooperative Research Program (TCRP) report 88 (3) provides a step-bystep process for developing a performance-measurement program. It describes the characteristics of an effective performance-measurement system and categorizes the performance measures. Data sources, data collection and management techniques that can be employed are described in this report. The program uses twelve case studies of successful performance-measurement programs and presents over 400 performance measures. Regarding safety, this report introduces five categories of safety and security goals as shown in Table 1.

Another interesting topic related to transit performance is the examination of the relationship between system performance indicators. Some studies have previously found the correlation between effectiveness and efficiency. Karlaftis and McCarthy (15) found that efficiency and effectiveness of a system are strongly related. However, their results disagreed with the findings of Chu et al. (16) who reported efficient systems are not necessarily effective. The reason behind this difference may be the different sets of data used in these studies.

What becomes quite apparent from the results of previous works is that there is a distinct lack of assessing transit safety performance and examining the relationship between safety indicators and the remaining attributes. Also, from the literature review, it was ascertained not every performance measure is attainable from NTD, and they are not necessarily related to safety, such as the average age of revenue vehicle fleet or the average annual miles of service per revenue vehicle (8). Thus, a single indicator, 
or a smaller set of more reliable indicators, is needed to describe the transit safety performance.

Safety and Security Reporting Manual by the NTD explains how FTA funds are allocated to the transit agencies and what type of safety and security data are reported and are available to the public users (4). Also, the safety and security reporting forms are described and the process of completing and reporting incidents is clearly explained. Using this manual, the safety related data reported to the NTD was found.

TABLE 1.

Safety and Security Transit Performance Measures in TCRP

\begin{tabular}{|c|c|c|}
\hline Category & Performance Measures & Examples \\
\hline $\begin{array}{l}\text { Vehicle and } \\
\text { property } \\
\text { damage }\end{array}$ & $\begin{array}{l}\text { Accident Rate } \\
\text { Number of Fires }\end{array}$ & $\begin{array}{l}\text { - Vehicle accidents, Customer accidents } \\
\text { - A measure of system safety }\end{array}$ \\
\hline $\begin{array}{l}\text { Passenger } \\
\text { accidents }\end{array}$ & Passenger Safety & $\begin{array}{l}\text { - Fatal accidents per passenger-miles/VMT } \\
\text { - Injury accidents per passenger-miles/VMT } \\
\text { - Property-damage-only accidents per passenger } \\
\text { miles/VMT } \\
\text { - Response time } \\
\text { - Incident/accident durations }\end{array}$ \\
\hline $\begin{array}{l}\text { Accident } \\
\text { potential }\end{array}$ & $\begin{array}{l}\text { Drug-related accident potential } \\
\text { Bus operator accident potential } \\
\text { Rail operator accident potential } \\
\text { Maintenance-related accident } \\
\text { potential }\end{array}$ & $\begin{array}{l}\text { - Percent of positive drug/alcohol tests } \\
\text { - Number of traffic tickets issued to operators } \\
\text { - Percent of buses exceeding speed limit } \\
\text { - Number of station overruns } \\
\text { - Road calls } \\
\text { - Fleet maintenance performance }\end{array}$ \\
\hline $\begin{array}{l}\text { Workplace } \\
\text { safety }\end{array}$ & $\begin{array}{l}\text { Employee Work Days Lost to } \\
\text { Injury }\end{array}$ & - Number of work days lost to injury \\
\hline $\begin{array}{l}\text { Passenger } \\
\text { security }\end{array}$ & $\begin{array}{l}\text { The number of crimes committed } \\
\text { on transit property } \\
\text { The level of security provided } \\
\text { Customer perceptions of the } \\
\text { safety and security of the transit } \\
\text { system }\end{array}$ & $\begin{array}{l}\text { - Number of crimes (Crime rate) } \\
\text { - Ratio of transit police officers to transit vehicles } \\
\text { - Number (Percent) of vehicles with specified } \\
\text { safety devices } \\
\text { - Customer satisfaction } \\
\text { - Incidents of vandalism }\end{array}$ \\
\hline
\end{tabular}

\section{SAFETY PERFORMANCE MEASURE SELECTION}

From the past studies reviewed, the safety indicators and their use in the assessment of transit systems was found. In selecting the key indicators for performance evaluation, particular attention was given to the availability and reliability of data in the NTD, necessary for calculating each indicator. As an example, the number of crimes was omitted from the database due to a high percentage of missing information. Data came from a total of 930 urban transit agency reports to the NTD in 2012. It must be noted that data for purchased services versus directly operated are not included in the data sets. Table 2 lists 11 performance measures selected for analysis from the past studies. Indicators are classified into four groups: Vehicle safety, Transit riders' safety and security, Employee and operator safety, and Non-riders safety. 
TABLE 2.

Safety Transit Performance Measures

\begin{tabular}{|l|l|}
\hline \multicolumn{1}{|c|}{ Categories } & \multicolumn{1}{c|}{ Performance Measures } \\
\hline Vehicle safety & $\begin{array}{l}\text { 1. Accidents per 100,000 miles of service } \\
\text { 2. Accidents per 1,000 hours of service } \\
\text { 3. Number of Incidents per 1000 Vehicle Miles } \\
\text { 4. Number of Incidents per 1,000 passenger boarding } \\
\text { 5. Number of Fires }\end{array}$ \\
\hline $\begin{array}{l}\text { Transit riders } \\
\text { safety and security }\end{array}$ & $\begin{array}{l}\text { 1. Number of transit-riders injuries per 100 million PMT } \\
\text { 2. Number of transit-riders fatalities per 100 million PMT }\end{array}$ \\
\hline $\begin{array}{l}\text { Employee and } \\
\text { operator safety }\end{array}$ & $\begin{array}{l}\text { 1. Employees fatalities per } 100 \text { million VMT } \\
\text { 2. Employees injuries per 100 million VMT }\end{array}$ \\
\hline Non-riders safety & $\begin{array}{l}\text { 1. Non-occupant fatalities per 100 million VMT } \\
\text { 2. Non-occupant injuries per } 100 \text { million VMT }\end{array}$ \\
\hline
\end{tabular}

\section{COMPARISON BETWEEN DIFFERENT MODES SAFETY}

Prior to estimating the indicators, data were broken down by mode when more than one mode exists. One cannot assume the highest demanded agency has the best safety score (or less safety issues) because safety is directly related to the type of in-use modes. For example, a higher level of accidents is expected for an agency mostly accommodating passengers with bus compared to the other agency that uses heavy rail transit. It is quite clear that the probability of accidents with pedestrians, bicyclists and other vehicles is likely to be greater in the first mode. Furthermore, the amount of service produced and service consumed varies among modes which makes the safety ratios variable. In an attempt to check this assumption, a comparison was made between the safety indicator values of different modes. In doing so, it was necessary to classify modes of transit in different groups and then find the performance measures for the agencies operating the same mode. The "2012 National Transit Summaries and Trends" (NTST) prepared by the NTD (17) classifies the transit modes into seven categories as described in Table 3.

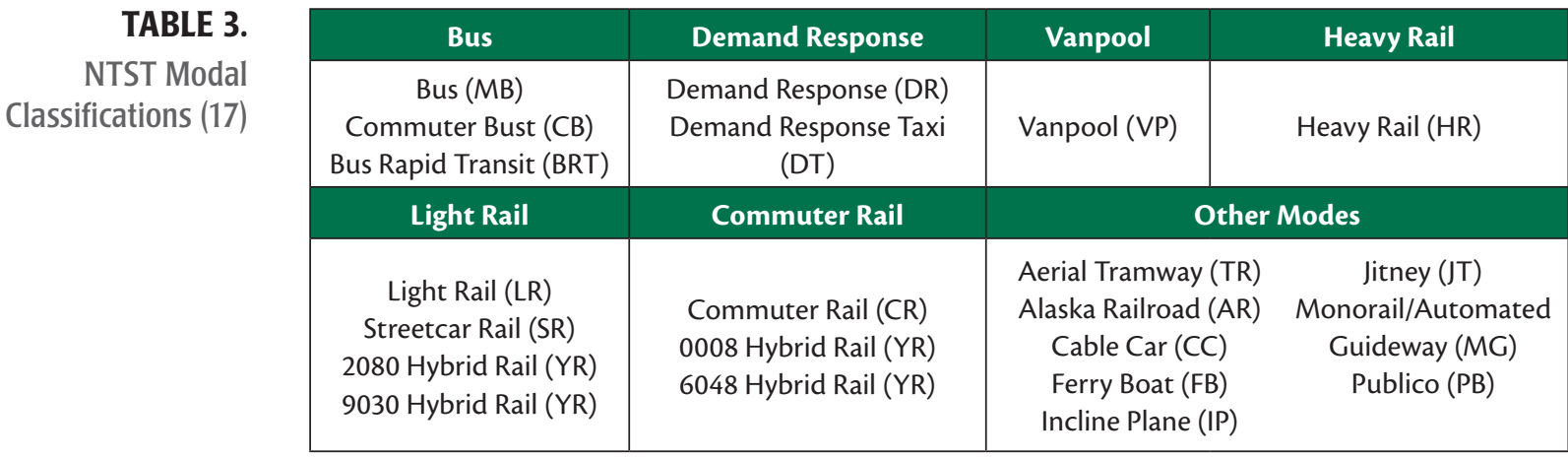

After splitting data, the percentages of agencies accommodating each category of modes were found to be 82 percent buses, 81 percent demand response (also called diala-ride or paratransit, provides services at the passenger's request), 12 percent vanpool, 2 percent heavy rail, 4 percent light rail, and 11 percent other types of transit modes 
$(O M)$. It should be noted that none of the agencies have reported commuter rail data to the NTD, this data, however, are reported to the Federal Railroad Administration (FRA). Figure 1 indicates that different modes provide different levels of safety.

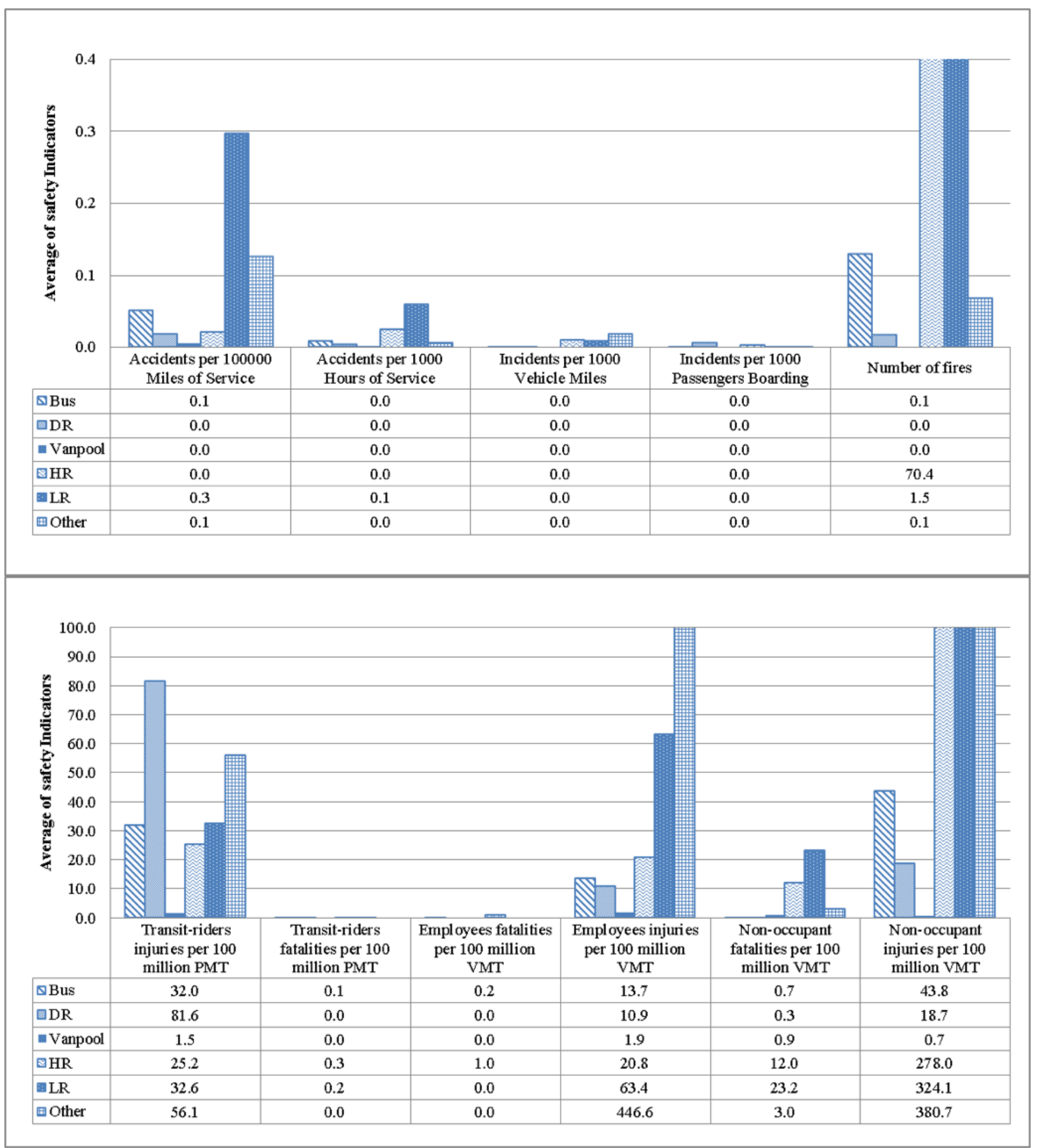

FIGURE 1. (a) Vehicle Safety for each Mode, (b) Riders, Non-riders, and Employees Safety for each Mode 
Fig 1 (a) shows the vehicle safety for each mode, and Fig 1(b) shows riders, non-riders, and employees' safety for each mode. The overall results show the variation between the safety indicators among transit modes. It is found from Fig. 1 that vanpool is the safest mode. The Vanpool Safety Brochure (18) identifies several reasons for this including: vanpool drivers have several years of experience driving, vanpools operate in urban areas and on major highways with safer speeds, having 14 passengers in van keeps most drivers operating in a safer manner, and drivers have been trained before operating the vehicle. The findings reveal that mostly the victims in transit-related accidents are non-occupants. Numbers are rounded up to one decimal degree. Transit riders' fatalities only account for 3.8 percent of all reportable fatalities in 2012 (17). According to the Figure 1, the greatest values of non-occupant's safety indicators are for rail transit modes (i.e. Heavy and Light Rail Transit), meaning that these systems have the highest safety issues for non-riders. Also, the rail transit vehicles experience the highest rate of injuries (riders, employees and non-occupants). Meanwhile, accident rate values are the highest for light rail transit mode. The least safety levels regarding the transit rider's injuries are found in demand response mode. The reason can be the medical fragility and/or age of many of the passengers using this mode of transportation.

\section{COMPARISON BETWEEN LARGE AND SMALL AREAS}

One of the most revealing types of analysis is the comparison between safety performance measures of different agencies. However, transit systems work in areas with different sizes. The area size might have effects on the safety that a system provides. Thus, it is useful to find which indicators are dependent on the size of the area before making any suggestions.

In this section of the study, analysis was conducted to investigate any association between the transit system's safety and area size. Within the NTD, a numeric code is assigned to the Census-designated Urbanized Area (UZA) variable, which indicates where the system primarily operates. Numbers are assigned sequentially from the largest UZA (\#1 = New York-Newark, NY-NJ-CT) to the smallest $(\# 452=$ Fond du Lac, WI), with exceptions made for UZAs in Puerto Rico (numbered from \#500-\#511), the special Virgin Islands UZA (only applies to FTA grants, numbered \#600), and one UZA that was added after the initial UZA definitions were published (\#453-Cumberland, MD-WV-PA) (3). Since the population of each area is not recorded in NTD, the comparison was made between the first half of the UZA codes, showing the larger areas, and the second half, indicating the small areas.

Data in Table 4 presents the average safety performance measures for large and small areas with regards to the transit mode. The $\mathrm{p}$-values came from the results of a t-test, to compare the safety between the two areas. The sample size for each mode of transit in large and small areas are as follows: 270 and 380 for bus system; 241 and 392 for DR system; 49 and 23 for Vanpool mode and 27 and 9 for other modes. It should be noted that it was practically impossible to make a comparison between rail transit safety in large and small cities due to the lack of rail transit systems in small areas. 
TABLE 4.

Large vs. Small Areas

Safety Indicator Values

\begin{tabular}{|c|c|c|c|c|}
\hline \multicolumn{5}{|c|}{ Average values (Large area vs. Small area (p-value)) } \\
\hline Safety Indicators & Bus & DR & Vanpool & OM \\
\hline $\begin{array}{l}\text { Accidents per } 100000 \text { Miles of } \\
\text { Service }\end{array}$ & $\begin{array}{l}0.05 \text { vs. } 0.05 \\
(0.71)\end{array}$ & $\begin{array}{l}0.03 \text { vs. } 0.01 \\
(0.03)^{*}\end{array}$ & $\begin{array}{l}0.00 \text { vs. } 0.00 \\
(0.79)\end{array}$ & $\begin{array}{l}0.17 \text { vs. } 0.00 \\
(0.20)\end{array}$ \\
\hline $\begin{array}{l}\text { Accidents per } 1000 \text { Hours of } \\
\text { Service }\end{array}$ & $\begin{array}{l}0.01 \text { vs. } 0.01 \\
(0.97)\end{array}$ & $\begin{array}{l}4.1 \mathrm{E}-03 \text { vs. } \\
1.8 \mathrm{E}-03(0.03) *\end{array}$ & $\begin{array}{l}0.00 \text { vs. } 0.00 \\
(0.79)\end{array}$ & $\begin{array}{l}6.2 \mathrm{E}-03 \text { vs. } \\
4.6 \mathrm{E}-05(0.07) *\end{array}$ \\
\hline Incidents per $1000 \mathrm{VMT}$ & $\begin{array}{l}0.00 \text { vs. } 0.00 \\
(0.65)\end{array}$ & $\begin{array}{l}0.00 \text { vs. } 0.00 \\
(0.54)\end{array}$ & $\begin{array}{l}0.00 \text { vs. } 0.00 \\
(0.80)\end{array}$ & $\begin{array}{l}0.02 \text { vs. } 0.01 \\
(0.07)^{*}\end{array}$ \\
\hline $\begin{array}{l}\text { Incidents per } 1000 \text { Passengers } \\
\text { Boarding }\end{array}$ & $\begin{array}{l}1.5 \mathrm{E}-03 \text { vs. } \\
1.4 \mathrm{E}-03(0.08) *\end{array}$ & $\begin{array}{l}0.01 \text { vs. } 0.00 \\
(0.99)\end{array}$ & $\begin{array}{l}0.00 \text { vs. } 0.00 \\
(0.80)\end{array}$ & $\begin{array}{l}1.6 \mathrm{E}-03 \text { vs. } \\
1.5 \mathrm{E}-04(0.03) *\end{array}$ \\
\hline Number of fires & $\begin{array}{l}0.25 \text { vs. } 0.04 \\
(0.00)^{*}\end{array}$ & $\begin{array}{l}0.01 \text { vs. } 0.02 \\
(0.72)\end{array}$ & $\begin{array}{l}0.00 \text { vs. } 0.00 \\
\left(\text { Note }^{2}\right)\end{array}$ & $\begin{array}{l}0.10 \text { vs. } 0.02 \\
(0.20)\end{array}$ \\
\hline $\begin{array}{l}\text { Transit riders injuries per } 100 \\
\text { million PMT }\end{array}$ & $\begin{array}{l}22.31 \text { vs. } 42.15 \\
(0.01) *\end{array}$ & $\begin{array}{l}57.02 \text { vs. } \\
103.80(0.23)\end{array}$ & $\begin{array}{l}1.42 \text { vs. } 1.75 \\
(0.87)\end{array}$ & $\begin{array}{l}75.52 \text { vs. } 0.78 \\
(0.04) *\end{array}$ \\
\hline $\begin{array}{l}\text { Transit riders fatalities per } 100 \\
\text { million PMT }\end{array}$ & $\begin{array}{l}0.09 \text { vs. } 0.11 \\
(0.84)\end{array}$ & $\begin{array}{l}0.04 \text { vs. } 0.00 \\
(0.32)\end{array}$ & $\begin{array}{l}0.00 \text { vs. } 0.00 \\
\left(\text { Note }^{2}\right)\end{array}$ & $\begin{array}{l}0.00 \text { vs. } 0.00 \\
\left(\text { Note }^{2}\right)\end{array}$ \\
\hline $\begin{array}{l}\text { Employees and operators } \\
\text { fatalities per } 100 \text { million VMT }\end{array}$ & $\begin{array}{l}0.00 \text { vs. } 0.32 \\
(0.40)\end{array}$ & $\begin{array}{l}0.00 \text { vs. } 0.00 \\
\left(\text { Note }^{1}\right)\end{array}$ & $\begin{array}{l}0.00 \text { vs. } 0.00 \\
\left(\text { Note }^{2}\right)\end{array}$ & $\begin{array}{l}0.00 \text { vs. } 0.00 \\
\left(\text { Note }^{2}\right)\end{array}$ \\
\hline $\begin{array}{l}\text { Employees and operators } \\
\text { injuries per } 100 \text { million VMT }\end{array}$ & $\begin{array}{l}12.62 \text { vs. } 14.53 \\
(0.67)\end{array}$ & $\begin{array}{l}8.62 \text { vs. } 12.30 \\
(0.65)\end{array}$ & $\begin{array}{l}2.82 \text { vs. } 0.00 \\
(0.11)\end{array}$ & $\begin{array}{l}595.40 \text { vs. } 0.00 \\
(0.17)\end{array}$ \\
\hline $\begin{array}{l}\text { Non-occupant fatalities per } \\
100 \text { million VMT }\end{array}$ & $\begin{array}{l}0.88 \text { vs. } 0.54 \\
(0.52)\end{array}$ & $\begin{array}{l}0.22 \text { vs. } 0.36 \\
(0.65)\end{array}$ & $\begin{array}{l}0.11 \text { vs. } 2.70 \\
(0.35)\end{array}$ & $\begin{array}{l}4.02 \text { vs. } 0.00 \\
(0.26)\end{array}$ \\
\hline $\begin{array}{l}\text { Non-occupant injuries per } 100 \\
\text { million VMT }\end{array}$ & $\begin{array}{l}45.45 \text { vs. } 42.70 \\
(0.77)\end{array}$ & $\begin{array}{l}27.12 \text { vs. } 13.49 \\
(0.25)\end{array}$ & $\begin{array}{l}1.03 \text { vs. } 0.00 \\
(0.23)\end{array}$ & $\begin{array}{l}506.52 \text { vs. } 3.25 \\
(0.03) *\end{array}$ \\
\hline
\end{tabular}

*statistically significant

'The number of employees' fatality is zero

'The number of riders' fatality is zero

Table 4 reveals that there is a significant difference between the bus systems safety in large and small areas in terms of Incidents per 1000 Passengers Boarding, Number of fires, and Transit riders' injuries per 100 million PMT. Results indicate that in small areas bus fleets operate safer while transit riders are more likely to be injured. Similarly, it could be concluded from the DR and OM safety indicator values that higher vehicle safety is provided in small areas. Regarding the transit riders and non-riders, OM provides a safer environment in the small areas.

\section{THE RELATIONSHIP BETWEEN SAFETY AND EFFECTIVENESS}

In order to identify the appropriate indicators to be included within the NTD profiles, the relationship between the system effectiveness and safety performance measures was investigated.

Correlations between data items will be valuable for examining the relationship between two sets of data. Consistent results across the safety and effectiveness indicators would provide evidence that the more effective a system is, the more safety it provides. In order to examine this assumption, the correlation coefficient was employed. The equation for the correlation coefficient is as follows: 


$$
\operatorname{Correl}(X, Y)=\frac{\sum(x-\bar{x})(y-\bar{y})}{\sqrt{\sum(x-\bar{x})^{2} \sum(y-\bar{y})^{2}}}
$$

Where, $\bar{X}$ and $\bar{Y}$ are the sample means of each pair of safety indicators and effectiveness indicators for each mode. The strength of an association is graded from zero to 1.00 and the direction of the relationship is expressed by a positive sign (+) if the relationship is direct, and by a negative sign (-) if the relationship is inverse. In order to find how strong a relationship is, three criteria are defined:

1. Correlations above 0.80 are regarded as high

2. Correlations between 0.50 and 0.80 are considered moderate

3. Correlations below 0.50 are regarded as low

Table 5 and Table 6 show the correlation coefficient for each pair of indicators.

\begin{tabular}{|c|c|c|c|c|c|c|c|}
\hline \multirow{15}{*}{$\begin{array}{r}\text { TABLE } 5 . \\
\text { Vehicle safety } \\
\text { performance } \\
\text { Measures vs. Service } \\
\text { effectiveness }\end{array}$} & $\begin{array}{c}\text { Service } \\
\text { Effectiveness }\end{array}$ & $\begin{array}{l}\text { Transit } \\
\text { Mode }\end{array}$ & $\begin{array}{l}\text { Accidents per } \\
100000 \text { Miles } \\
\text { of Service }\end{array}$ & $\begin{array}{l}\text { Accidents } \\
\text { per } 1000 \\
\text { Hours of } \\
\text { Service }\end{array}$ & $\begin{array}{l}\text { Incidents } \\
\text { per } 1000 \\
\text { VMT }\end{array}$ & $\begin{array}{l}\text { Incidents } \\
\text { per } 1000 \\
\text { Passengers } \\
\text { Boarding }\end{array}$ & $\begin{array}{l}\text { Number } \\
\text { of fires }\end{array}$ \\
\hline & \multirow{6}{*}{$\begin{array}{l}\text { unlinked passenger } \\
\text { trip per vehicle } \\
\text { revenue mile }\end{array}$} & Bus & 0.11 & 0.05 & 0.15 & -0.06 & 0.15 \\
\hline & & DR & 0.02 & 0.01 & -0.03 & -0.08 & -0.06 \\
\hline & & Vanpool & 0.13 & 0.11 & 0.13 & 0.03 & Note $^{1}$ \\
\hline & & $\mathrm{HR}$ & -0.25 & -0.27 & 0.14 & $-0.76^{*}$ & 0.56 \\
\hline & & LR & 0.37 & -0.02 & 0.29 & -0.18 & 0.30 \\
\hline & & OM & 0.21 & 0.14 & 0.15 & -0.09 & 0.00 \\
\hline & \multirow{6}{*}{$\begin{array}{l}\text { unlinked passenger } \\
\text { trip per vehicle } \\
\text { revenue hour }\end{array}$} & Bus & 0.14 & 0.09 & 0.18 & -0.03 & 0.17 \\
\hline & & DR & 0.10 & 0.10 & -0.03 & -0.07 & -0.05 \\
\hline & & Vanpool & 0.16 & 0.15 & 0.16 & 0.07 & Note $^{1}$ \\
\hline & & $\mathrm{HR}$ & -0.15 & 0.03 & 0.34 & -0.51 & $0.77^{*}$ \\
\hline & & LR & -0.05 & 0.40 & 0.26 & 0.14 & 0.30 \\
\hline & & $\mathrm{OM}$ & 0.04 & -0.01 & 0.03 & -0.05 & -0.02 \\
\hline & \multicolumn{7}{|c|}{$\begin{array}{l}{ }^{1} \text { Number of fires is zero for all agencies. } \\
\text { * Significant }\end{array}$} \\
\hline & \multicolumn{7}{|c|}{$\begin{array}{l}\text { The greater value of the safety indicator shows the less safety of the system. Thus, } \\
\text { having a positive correlation means the higher effective systems are less safe. According } \\
\text { to the Table 5, the number of incidents per } 1000 \mathrm{VMT} \text {, as well as the number of fires } \\
\text { in heavy rail systems is positively correlated with the effectiveness of the systems. } \\
\text { Surprisingly, the more effective heavy rail systems are more likely to have fire incidents, } \\
\text { and more incidents per VMT will occur. }\end{array}$} \\
\hline
\end{tabular}


TABLE 6.

Transit-riders,

Employees, and

Non-rider Safety and

Security Indicators

vs. Effectiveness

Indicators

\begin{tabular}{|c|c|c|c|c|c|c|c|}
\hline $\begin{array}{c}\text { Service } \\
\text { Effectiveness }\end{array}$ & Mode & $\begin{array}{c}\text { Transit } \\
\text { Riders } \\
\text { Fatalities } \\
\text { per } 100 \\
\text { million } \\
\text { PMT }\end{array}$ & $\begin{array}{c}\text { Transit } \\
\text { Riders } \\
\text { Injuries } \\
\text { per } 100 \\
\text { million } \\
\text { PMT }\end{array}$ & $\begin{array}{c}\text { Employees } \\
\text { and } \\
\text { operator } \\
\text { fatalities } \\
\text { per } 100 \\
\text { million } \\
\text { VMT }\end{array}$ & $\begin{array}{l}\text { Employees } \\
\quad \text { and } \\
\text { operator } \\
\text { injuries } \\
\text { per } 100 \\
\text { million } \\
\text { VMT }\end{array}$ & $\begin{array}{c}\text { Non- } \\
\text { occupant } \\
\text { fatalities } \\
\text { per } 100 \\
\text { million } \\
\text { VMT }\end{array}$ & 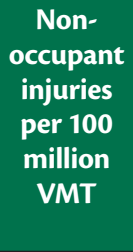 \\
\hline \multirow{6}{*}{$\begin{array}{l}\text { unlinked } \\
\text { passenger } \\
\text { trip per } \\
\text { vehicle } \\
\text { revenue mile }\end{array}$} & Bus & -0.02 & -0.05 & 0.02 & 0.07 & 0.09 & 0.05 \\
\hline & DR & -0.04 & -0.03 & Note $^{2}$ & -0.01 & -0.05 & 0.11 \\
\hline & Vanpool & Note $^{1}$ & 0.18 & Note $^{2}$ & -0.05 & -0.02 & -0.06 \\
\hline & $\mathrm{HR}$ & -0.24 & -0.28 & -0.24 & 0.23 & -0.12 & -0.04 \\
\hline & LR & -0.23 & 0.01 & Note $^{2}$ & 0.13 & -0.24 & 0.35 \\
\hline & OM & Note $^{1}$ & -0.01 & Note $^{2}$ & 0.18 & -0.06 & 0.04 \\
\hline \multirow{6}{*}{$\begin{array}{l}\text { unlinked } \\
\text { passenger } \\
\text { trip per } \\
\text { vehicle } \\
\text { revenue } \\
\text { hour }\end{array}$} & Bus & -0.02 & -0.06 & 0.02 & 0.08 & 0.10 & 0.07 \\
\hline & DR & -0.02 & -0.06 & Note $^{2}$ & -0.02 & 0.00 & 0.19 \\
\hline & Vanpool & Note $^{1}$ & 0.20 & Note $^{2}$ & -0.05 & 0.05 & -0.04 \\
\hline & $\mathrm{HR}$ & -0.25 & -0.09 & -0.10 & 0.06 & -0.01 & 0.23 \\
\hline & LR & 0.12 & -0.16 & Note $^{2}$ & 0.01 & 0.27 & 0.22 \\
\hline & OM & Note $^{1}$ & -0.04 & Note $^{2}$ & 0.04 & -0.03 & 0.00 \\
\hline
\end{tabular}

${ }^{1}$ Number of riders' fatality is zero

${ }^{2}$ Number of employees' fatality is zero

As no significant relationship was found between the safety and effectiveness indicators, one cannot conclude that the service effectiveness reflects the safety condition. Therefore, it is advantageous to ask the agencies report a set of safety indicators through NTD profiles.

\section{SUGGESTING SAFETY PERFORMANCE INDICATORS}

In order to select which indicators can represent the safety condition of the system, it is necessary to remove those highly dependent on the area size and effectiveness measures. In doing so, the results from Table 4 and Table 5 were taken into consideration.

From Table 4 it was found that:

- Considering 756 agencies operating DR, the value of "Accidents per 100000 Miles of Service" depends on the area size.

- Considering 786 agencies operating DR and OM the variable of "Accidents per 1000 Hours of Service" significantly depends on the area size.

- Variable of "incidents per 1000 Passengers Boarding", the same as the previous indicator, depends on the area size. A total of 783 agencies all over the U.S. (operating bus and $\mathrm{OM}$ ) provide different level of safety in terms of incidents per 1000 Passengers Boarding based on their area size. 
- The indicator of "number of fires" and "transit riders' injuries per 100 million PMT" have the same issue with area size.

From Table 5 it was found that:

- "Incidents per 1000 Passengers Boarding" as well as "the number of fires" in heavy rail systems are positively correlated with the effectiveness of the systems.

- "Number of transit Riders fatalities per 100 million PMT" and "Employees and operators fatalities per 100 million VMT" cannot be selected since a large number of systems did not experience riders or employees fatalities.

- The number of transit-riders injuries per 100 million PMT and the number of transit-riders fatalities per 100 million PMT cannot be calculated for one third of the agencies operating buses (323 out of 930) as they do not report PMT data to the NTD.

- Finally, the following indicators are suggested to be reported by transit agencies to the NTD:

1. Incidents per $1000 \mathrm{VMT}$

2. Employees' and operators' injuries per 100 million VMT

3. Non-occupant fatalities per 100 million VMT

Injuries among Transit Riders per 100 million PMT

The last indicator showing the riders' safety needs all agencies to provide the passenger mile traveled data to the NTD.

\section{CONCLUSION}

The research reported in this paper established a set of indicators that are particularly useful for the evaluation of transit systems safety performance. To accomplish this, past studies were reviewed to find out how a transit system's safety performance is measured. The following criteria were used to collect a set of safety indicators from the available measures:

1. Variables collected by the agencies and reported to the NTD

2. Indicators that are easily understood by transit managers.

This study additionally strived to demonstrate whether or not there is a tangible perceptual differences among the variety of safety indicators in small and large areas. The higher values of safety performance measures were found for buses, DR and other modes (rather than rail transit) operating in small areas compared with large areas. Moreover, rail transit was found to have the high safety problems between all modes. Summing up the findings, it was concluded that the transit vehicles have higher safety issues in larger urbanized areas. 
In order to suggest the safety indicators to be included within the NTD profiles, the relationship between the system effectiveness and safety performance measures was investigated. As no significant relationship was found between the safety and effectiveness indicators it was concluded that systems with high safety level do not necessarily perform effectively and vice versa.

The indicators best representing the system's safety performance were suggested as "Incidents per 1000 VMT", "Employees and operators injuries per 100 million VMT", and "Non-occupant fatalities per 100 million VMT".

Recently, some changes have been made in the Safety and Security Reporting Requirements that specifies how safety-related problems have to be reported in detail and highlights the importance of having safety measures (4). For example,

"Collisions involving transit vehicles that require towing away from the scene for a transit roadway vehicle or other non-transit roadway vehicle are automatically reportable" or "Rail transit vehicle collisions occurring at a grade crossing are automatically reportable." Addition of "Geographic location Longitude/Latitude" to the Basic Information Screen, also enables researchers to find the association between the characteristics of the service area and the level of safety.

Finally, it is important to remember this study does not show causation, but a relationship between service effectiveness and safety performance measures. This study does not ignore the importance of reporting safety data, but it suggests that the available and reliable data must be used to determine and present the most applicable and meaningful safety indicators of every system. Reporting more detailed information to the NTD makes it possible to consider new safety indicators. Therefore, it would be advantageous to keep exploring the relationship between the service performance measures to avoid presenting strongly correlated indicators together in a single report.

\section{REFERENCES}

1. Federal Transit Administration, National Transit Database, U.S. Department of Transportation, Washington, DC, 2000. http://www.ntdprogram.com.

2. Akoto, E.V. (2016). Exploring Diversified Performance Indicators for Evaluating NonUrbanized Transit Program Outcomesm, Journal of Public Transportation, 19(1):2848.

3. Ryus, P. (2003). A Summary of TCRP Report 88: A Guidebook for Developing a Transit Performance-Measurement System. TCRP Research Results Digest, (56).

4. National Transit Database (2015). Safety \& Security Reporting Manual. Office of Budget and Policy.

5. Federal Transit Administration. (2002). Transit Profiles, 2000 Report Year, Washington, DC.

6. Benjamin, J., Obeng, K. (1990). The effect of policy and background variables on total factor productivity for public transit. Transportation Research 24B (1), 1-14. 
7. Fielding, G. J., Babitsky, T. T., \& Brenner, M. E. (1985). Performance evaluation for bus transit. Transportation Research Part A: General, 19(1), 73-82.

8. Majumdar, S. R., Highsmith, M., Cherrington, L., \& Weatherby, C. (2011). Performance measures for public transit mobility management (No. FHWA/ TX-12/0-6633-1). Texas Transportation Institute, Texas A\&M University System.

9. U.S. Department of Transportation. Transportation for a New Generation. Strategic Plan for Fiscal Years 2012-16.

10. Valley Metro/Regional Public Transportation Authority. (2007). Efficiency and Effectiveness Study. Project No. 064008S.

11. USF Center for Urban Transportation Research. (2009). Best Practices in Transit Service Planning. Final Report.

12. Fielding, G. J. (1992). Transit performance evaluation in the USA. Transportation Research Part A: Policy and Practice, 26(6), 483-491.

13. Anderson, M., \& Khan, T. (2014). Performance Measures for the Analysis of Rural Public Transit in Alabama. Journal of Public Transportation, 17(4), 2.

14. Livermore Amador Valley Transit Authority. http://www.wheelsbus.com/

15. Karlaftis, M. G., \& McCarthy, P. S. (1997). Subsidy and public transit performance: A factor analytic approach. Transportation, 24(3), 253-270.

16. Chu, X., Fielding, G. J., \& Lamar, B. W. (1992). Measuring transit performance using data envelopment analysis. Transportation Research Part A: Policy and Practice, 26(3), 223-230.

17. National Transit Database. (2013). 2012 National Transit Summaries and Trends. Office of Budget and Policy.

18. Web, Vanpool Safety Brochure, ACT Vanpool Council and ACT Government Affairs Specialist Jason Pavluchuk. Available at: http://actweb.org/wp-content/ uploads/2014/12/ACT_Vanpool_safety_brochure.pdf 